\title{
Laura Quick* \\ Averting Curses in the Law of War (Deuteronomy 20)
}

https://doi.org/10.1515/zaw-2020-2001

According to a number of scholars, Deuteronomy 20 presents a veritable »manual of war «. ${ }^{1}$ Despite these assertions, Deuteronomy 20 or the »law of war« does not provide a systematic set of instructions relating to the practice of warfare, and the first nine verses preserve not laws at all but an oratory address spoken to the Israelite army prior to battle, and delivered by both priests and officers. Deut 20:1-9 thus describes the role of these priests and officers in preparing the troops for battle. In vv. 10-18, we find a prescription for the correct treatment of captured cities, with a geographic distinction concerning appropriate behaviour towards one's enemies. ${ }^{2}$ Finally, vv. 19-20 outline the treatment of trees in conquered territories. It is these latter two pericopes which have been the primary focus of much of the scholarship on the law of war. Concerning vv. 10-18, scholars have considered the Neo-Assyrian background of the prescriptions, ${ }^{3}$ as well as the process of harmonization that has seen disparate traditions of varying war ideologies combined in order to craft the extant version of the text. ${ }^{4}$ In the case of

1 Eugene H. Merrill, Deuteronomy, NAC 4 (Nashville: Broadman \& Homan, 1994), 282.

2 Deut 20:10-14 calls upon attackers to offer the residents of the besieged city the possibility of surrender. However, in v. 15 the applicability of the laws of vv. 10-14 are limited only to towns which stand at a geographic distance to Israel, and vv. 16-18 outline a different procedure for local towns, involving the execution of all residents.

3 See Norbert Lohfink, Krieg und Staat im alten Israel, BzF 14 (Barsbüttel: Institut für Theologie und Frieden, 1992), 15; Eckart Otto, Das Deuteronomium: Politische Theologie und Rechtsreform in Juda und Assyrien, BZAW 284 (Berlin: De Gruyter, 1999), 64; Carly L. Crouch, War and Ethics in the Ancient Near East: Military Violence in Light of Cosmology and History, BZAW 407 (Berlin: De Gruyter, 2009), 184-188.

4 See Alexander Rofé, »The Laws of Warfare in the Book of Deuteronomy: Their Origins, Intent and Positivity«, JSOT 32 (1985) 23-44: 26-29; Michael Fishbane, Biblical Interpretation in Ancient Israel (Oxford: Oxford University Press, 1985), 220; Susan Niditch, War in the Hebrew Bible: A Study in the Ethics of Violence (Oxford: Oxford University Press, 1993), $11 \mathrm{f} . ; 65$.

Article note: With thanks to Dr Louis Rawlings.

*Kontakt: Laura Quick, Worcester College, Walton Street, Oxford, OX1 2HB, UK, E-Mail: laura.quick@theology.ox.ac.uk 
vv. 19-20, the main concern has been the origin of the surprising requirement not to chop down the trees found in enemy territories, and scholars have variously sought the background of this law against Neo-Assyrian ${ }^{5}$ or Neo-Babylonian ${ }^{6}$ military tactics, although a number of scholars have also pointed towards the second millennium for the practices which gave rise to the law. ${ }^{7}$ In fact, the destruction of enemies' crops as a tactic in siege warfare is common to several periods of history, and the ancient Greeks were also known to engage in this. ${ }^{8}$

In the case of the oratory address which starts the law of war, the primary mode of inquiry has been literary-critical. The text in question reads:

When you go to war against your enemies and see horse and chariot and people who outnumber you, do not be afraid of them, for the Lord your God, who brought you up out of the land of Egypt, is with you. As you move forward for battle, the priest will approach and he will say to the people, >Listen, Israel! Today you are moving forward to do battle with your enemies. Do not be fainthearted. Do not fear and tremble or be terrified because of them, for the Lord your God goes with you to fight on your behalf against your enemies to give you victory. $<$ Moreover, the officers are to say to the people, `Who among you has built a new house and not dedicated it? He may go home, lest he die in battle and someone else dedicate it. Or who among you has planted a vineyard and not benefited from it? He may go home, lest he die in battle and someone else benefit from it. Or who among you has become

5 This was argued already by August Dillman, Die Bücher Numeri, Deuteronomium und Josua (Leipzig: Hinrichs, 1886), and has been followed by many subsequent commentators. See Samuel R. Driver, A Critical and Exegetical Commentary on Deuteronomy, ICC 5 (New York: Scribner's, 1916), 240; George Adam Smith, The Book of Deuteronomy in the Revised Version: With Introduction and Notes (Cambridge: Cambridge University Press, 1918), 249; Moshe Weinfeld, Deuteronomy and the Deuteronomic School (Oxford: Clarendon, 1972), 50 f.; Andrew D. H. Mayes, Deuteronomy, NCB (Grand Rapids: Eerdmans, 1976), 296; Eckart Otto, Krieg und Frieden in der Hebräischen Bibel und im Alten Orient (Stuttgart: Kohlhammer, 1999), 100; Nili Wazana, »Are the Trees of the Field Human? A Biblical War Law (Deut. 20:19-20) and Neo-Assyrian Propaganda «, in Treasures on Camels' Humps: Historical and Literary Studies from the Ancient Near East Presented to Israel Eph'al, ed. Mordechai Cogan and Dan'el Kahn (Jerusalem: Magnes, 2008) 275-295.

6 Norbert Lohfink, Theology of the Pentateuch: Themes of the Priestly Narrative and Deuteronomy (Minneapolis: Fortress, 1994), 55-75; Georg Braulik, The Theology of Deuteronomy: Collected Essays (Richland Hills: Bibal, 1994), 151-164; Ronald E. Clements, »The Deuteronomic Law of Centralization and the Catastrophe of $587 \mathrm{BC}$ «, in After the Exile: Essays in Honour of Rex Mason, ed. John Barton and David J. Reimer (Macon: Mercer University Press, 1996) 2-25. Josephus records that during the siege of Jerusalem, all trees within $15 \mathrm{~km}$ were cut down (Jewish War 6.151).

7 J.A. Thompson, Deuteronomy: An Introduction and Commentary, TOTC (Downers Grove: InterVarsity Press, 1974), 224; Peter C. Craigie, The Book of Deuteronomy, NICOT (Grand Rapids; Eerdmans, 1976), 276f.; Jeffrey H. Tigay, Deuteronomy, JPS Torah Commentary (Philadelphia: Jewish Publication Society, 1996), $190 \mathrm{f}$.

8 Victor Davis Hanson, Warfare and Agriculture in Classical Greece (Berkeley: University of California Press, 1998), 26. 
engaged to a woman but has not married her? He may go home, lest he die in battle and someone else take her. In addition, the officers are to say to the troops, ,Who among you is afraid and fainthearted? He may go home so that he will not make his fellow brother's heart as fearful as his own. Then, when the officers have finished speaking, they must appoint unit commanders to lead the troops (Deut 20:1-9).

As many scholars have noted, in this section of text the second person plural (vv. 2-4) is mixed with the second person singular (vv. 1, 5-9). In vv. 2-4, the priest demonstrates complete confidence in the Israelite military machine, whereas in vv. 5-9, the troops continue to express anxiety. The speakers are introduced and then re-introduced. Accordingly, almost all commentators agree that the text is composite, with vv. 5-7 as the earliest layer of text, before vv. 2-4 were added as a Priestly expansion. ${ }^{9}$ As well as literary-critical issues, a secondary concern has been to identify the reasons behind the exemptions in vv. 5-7. Many commentators have argued that the text betrays a strong humanitarian concern, without further comment. ${ }^{10} \mathrm{~A}$ more satisfying proposal has seen the text connected to religious concerns, albeit here too commentators have betrayed various levels of sophistication in their argumentation. Gerhard von Rad claimed that anyone who had anything to inaugurate such as a bridegroom or the planter of a vineyard was threatened »to an unusual extent « by demons, and hence these men were eliminated from the ranks in the interests of magical and ritual purity, to protect their fellow soldiers. He justifies these assertions on the basis of »very ancient and widespread beliefs «, although he provides no examples of these. ${ }^{11}$ Andrew Mayes similarly argues that persons who had recently built a house, planted a vineyard, or married a wife were particularly subject to demonic influences, suggesting that they were considered »taboo « by way of an explanation. ${ }^{12}$ Willem M. de Bruin has insightfully connected the verses in question to the futility curse found in Deut 28:30: »If you become engaged to a woman, another man shall violate her. If you

9 Gerhard von Rad, Deuteronomy: A Commentary, trans. Dorothea Barton (London: SCM, 1966), 131; Rofé, »The Laws of Warfare in the Book of Deuteronomy«: $34 \mathrm{f}$.; Ian Cairns, Word and Presence: A Commentary on the Book of Deuteronomy, ITC (Grand Rapids: Eerdmans, 1992), 182f.; Alexander Rofé, Deuteronomy: Issues and Interpretation (London: T\&T Clark, 2002), 165; Richard D. Nelson, Deuteronomy: A Commentary, OTL (Louisville: Westminster John Knox, 2002), 247.

10 Anthony Phillips, Deuteronomy (Cambridge: Cambridge University Press, 1973), 135; 136; Craigie, The Book of Deuteronomy, 273; Rofé, »The Laws of Warfare in the Book of Deuteronomy«: 37; Patrick D. Miller, Deuteronomy, Int. (Louisville: John Knox, 1990), 157; 159. Calum M. Carmichael, The Laws of Deuteronomy (Ithaca: Cornell University Press, 1974), 118-126, connects the exemption to the theological idea of "rest «, arguing that Deuteronomy emphasizes the idea of Israel's rest and security in the land over military excursions.

11 Von Rad, Deuteronomy, 131.

12 Mayes, Deuteronomy, 291. 
build a house, you shall not live in it. If you plant a vineyard, you shall not benefit from it." He argues that in a futility curse, the danger stems from the inversion of the natural relationship between an initial act and its expected consequence: thus, in the case of the first clause of Deut 28:30, for example, the expectation to have sex with one's wife following engagement and marriage. By undermining this expected order, the curse of futility therefore undermines the expected order of the cosmos itself. Accordingly, Deut 20:5-7 are intended to prevent the cosmic order from unravelling, while at the same time permitting the enjoyment of the good things granted by God. ${ }^{13}$

I agree with de Bruin that the futility curse is key to understanding the military exemption of Deuteronomy 20. However, in this essay I argue that this interpretation does not go far enough. Rather than merely an attempt to avoid the futility curse, vv. 5-7 can be productively understood as a ritual response to the curse of futility. This relates both to the social and ritual context of the curse of futility, as well as to the importance of pre-war rituals in the Hebrew Bible more generally. By exploring the ritual and performative elements of Deut 20:5-7 in light of rituals for avoiding curses and maledictions from the ancient Near East, I will argue that the original Sitz im Leben of these verses can be found in a pre-war ritual specifically responding to the hegemonic aims of enemies as this crystallized in both the inscriptional and ritual contexts of ancient warfare.

\section{The Futility Curse in Scripture and Inscription}

The law code of the book of Deuteronomy is capped with a series of curses that threaten harm upon the individuals subject to the Deuteronomic laws. While this might seem surprising from a theological point of view, curses were an integral part of the legal, political and religious life of the ancient Near East. The verb 'lh has the meaning »to pronounce a conditional curse «. ${ }^{14}$ Its derived noun 'âlâ is used in conjunction with the technical term $b^{e}$ rit, " treaty, covenant «, in Deut 29:20. Thus a $b^{e}$ rit refers to a bond between individuals or groups of individuals that is sanctioned and ratified by curses. ${ }^{15}$ Curses are thus central to the covenant or treaty relationship between Israel and God which is set out in the book of Deuteronomy. In fact, scholars have been quick to note the parallels that exist between the curses of the book of Deuteronomy with other ancient Near Eastern

13 Willem M. de Bruin, »Die Freistellung vom Militärdienst in Deut. xx 5-7«, VT 49 (1999) 21-33. 14 J. Scharbert, »'ālâ«, TDOT 1 (1977) 261-266: 261.

15 Indeed, 'ālâ stands in for berît in Gen 26:28, and for še bû'â, »oath « in Gen 24:8,41. 
treaty texts. In particular, a Neo-Assyrian treaty written in Akkadian in the seventh century всE, »The Succession Treaties of Esarhaddon« (»EST« for short) has been suggested by some scholars to provide direct parallels with some of the curses found in the book of Deuteronomy. ${ }^{16}$ While not everyone agrees about the nature of the relationship which gave rise to the parallels between Deuteronomy and the Succession Treaties, ${ }^{17}$ the curses of Deuteronomy can productively be understood in light of the treaty genre.

However, the past few decades have brought to light additional inscriptions that also provide paralleled phenomena to the curses in Deuteronomy. Unlike the Esarhaddon Treaty, these inscriptions are written in Old Aramaic, a Northwest Semitic language utilized in Syria during the first millennium BCE. Thus, these inscriptions are both geographically and linguistically closer to the biblical world than the Mesopotamian texts which scholars have previously referred to Deuteronomy. ${ }^{18}$ The particular curse formula common to the Old Aramaic inscriptions and the book of Deuteronomy can be described as curses of futility, with a characteristic syntactical form providing a protasis that defines an action of some kind, followed by an apodosis in which this action is frustrated. Several characteristic examples can be found in the Sefire treaties, three treaties written in Old Aramaic and discovered near Aleppo:

And should seven mares nurse a colt, may it not be sa[ted. And should seven] cows nurse a calf may it not be sated. And should seven ewes nurse a lamb, [may it not be sa]ted.

wašaba' sūsyāh yuhayniqān 'īl wa'al yišs[ba' wašaba'] šawrāh yuhayniqān 'igl wa'al yiśba' wašaba‘ ša'ān yuhayniqān 'immēr wa['al yiśba'] (KAI 222 A1:22-23).

16 Rintje Frankena, »The Vassal-Treaties of Esarhaddon and the Dating of Deuteronomy«, OudSt 14 (1965) 122-154; Moshe Weinfeld, »Traces of Assyrian Treaty Formulae in Deuteronomy«, Biblica 46 (1965) 417-427; idem, Deuteronomy and the Deuteronomic School, 119-121; Hans-Ulrich Steymans, Deuteronomium 28 und die adê zur Thronfolgeregelung Asarhaddons: Segen und Fluch im Alten Orient und in Israel, OBO 145 (Göttingen: Vandenhoeck \& Ruprecht, 1995); Bernard M. Levinson, » But You Shall Surely Kill Him! «: The Text-Critical and Neo-Assyrian Evidence for MT Deuteronomy 13:10«, in Bundesdokument und Gesetz: Studien zum Deuteronomium, ed. G. Braulik, HBS 4 (Freiburg: Herder, 1995) 37-63; Eckart Otto, Gottes Recht als Menschenrecht: Rechtsund literaturhistorische Studien zum Deuteronomium (Wiesbaden: Harrassowitz, 2008); Bernard M. Levinson, „Esarhaddon's Succession Treaty as the Source for the Canon Formula in Deuteronomy 13:1", JAOS 130 (2010) 337-347; Bernard M. Levinson and Jeffrey Stackert, »Between the Covenant Code and Esarhaddon's Succession Treaty", JAJ 3 (2012) 123-140.

17 See the discussion of the debate between Bernard Levinson and Jeffrey Stackert with Joshua Berman in Laura Quick, Deuteronomy 28 and the Aramaic Curse Tradition (Oxford: Oxford University Press, 2017), 41-68.

18 Laura Quick, »»But You Shall Surely Report Concerning Him«: In Defense of the Priority of LXX Deuteronomy 13:9«, ZAW 130 (2018) 86-100. 
Many biblical texts utilize this curse form, with a total of forty-three discrete examples of the futility curse across all biblical books, found especially in Deuteronomy and in pre-exilic prophetic texts. ${ }^{19}$ Meanwhile, across the corpus of Old Aramaic inscriptions, there are nineteen occurrences of the futility curse, stemming from three separate inscriptions datable within the range of the ninth to the eighth centuries BCE, and with a geographic distribution across the Trans- and Cisjordan: from the Tell Fakhariyah bilingual inscription (x6); the Sefire treaties (x11); and the recently discovered stele from Bukān (x2). ${ }^{20}$ The regularity of these futility curses demonstrates that it was a standard literary form which was utilized by Northwest Semitic scribes in the first-millennium BсE. ${ }^{21}$ Recently, I have argued that this is important for understanding Deuteronomy; thus the curses of Deuteronomy 28 mediate between the traditions of East and West, featuring characteristic examples of the Northwest Semitic futility curse, as well as curses more common to Akkadian, East Semitic texts like the Esarhaddon Treaties. ${ }^{22}$ This is the case with Deut 28:30, the curse which is important for understanding the law of war and its military exemptions. Thus Deut 28:30 coheres with the tradition of the futility curse. At the same time, the Esarhaddon Treaties still provide the conceptual framework for the curse:

May Venus, the brightest of the stars, before your eyes make your wives lie in the lap of your enemy; may your sons not take possession of your house, but a strange enemy divide your goods.

delebat nabât kakkabāni ina nițil īnīkunu hīrātīkunu ina sūn nakirīkunu lišanīl mārīkunu aji ibēlū bìtkun nakiru ahû liza"'za mimmûkun (SAA 2, 3).

If you become engaged to a woman, another man shall violate her. If you build a house, you shall not live in it. If you plant a vineyard, you shall not benefit from it.

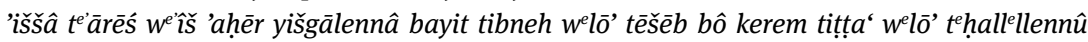
(Deut 28:30).

Here Deuteronomy develops the idea world of the parallel curse in the Esarhaddon Treaties-so violated wives and houses in which the owner cannot residebut couches these motifs in the characteristic syntactic form of the futility curse, expanding upon the Akkadian by adding a further clause that develops a tradi-

19 Lev 26:26; Deut 28:30(x3),31(x3),38,39,40,41; Isa 5:10(x2); Jer 11:11; Hos 2:9(x2); 4:10 (x2); 5:6; 8:7; 9:12,16; Amos 4:8; 5:11(x2); 8:12; Micah 3:4; 6:14(x2),15(x3); Zeph 1:13(x2); Hag 1:6 (x4); Zech 7:13; Mal 1:4; Ps 127:1; Job 31:8; and Prov 1:28(x2).

20 Quick, Deuteronomy 28 and the Aramaic Curse Tradition, 68-106.

21 See also Melissa Ramos, „A Northwest Semitic Curse Formula: The Sefire Treaty and Deuteronomy 28«, ZAW 128 (2016) 205-220.

22 Quick, Deuteronomy 28 and the Aramaic Curse Tradition, 137-158. 
tional Northwest Semitic motif concerning frustrated vineyards. ${ }^{23}$ In fact, these particular threats are common in the Hebrew Bible, and as well as in Deut 28:30 the threat of frustrated houses and vineyards is found in a number of places in biblical literature. ${ }^{24}$ The converse of the curse, building houses to live in and planting vineyards to eat and drink from, is frequently utilized in images of blessing and divine favour. ${ }^{25}$

These recognitions have implications for understanding the social-cultural background of the futility curses in Deuteronomy 28. These curses are linked to both the Neo-Assyrian and the Levantine genres of treaty and monument. Recently, Jacob Lauinger has considered the ritual context of Esarhaddon's Succession Treaties. The tablets are sealed with Aššur's seal of destinies, thereby transforming the tablet into a »Tablet of Destinies«, with the stipulations inscribed upon them becoming the actual destinies of those named. Lauinger suggests that the decreeing of destinies inscribed on the tablets was performed annually at the akitu or New Year ceremony, and that the representatives of the various vassal kingdoms and provinces presented their annual tribute in conjunction with this. ${ }^{26}$ Nathaniel Levtow has considered the ideological dimensions of Levantine monumental inscriptions in the context of ancient warfare. Installed in strategic places, requiring special interactions such as public proclamations and sacrifices, and involving powerful social agents such as priests or kings, these monuments can configure specific social environments. ${ }^{27}$ Thus the Sefire Treaty is explicit that »not one word of this inscription be silent « (KAI 222: A1 8). ${ }^{28}$ These inscriptions, themselves written artifacts, develop and demand a particular attitude towards the ritual performance of written text.

Inherent to both these arguments, then, is the ritual dimension inherent to the pronouncement of curses in the Neo-Assyrian and Levantine genres of treaty

23 On the Northwest Semitic background of the curse against the vineyard, see Jeremy D. Smoak, »Building Houses and Planting Vineyards: The Inner-Biblical Discourse on an Ancient Israelite Wartime Curse«, JBL 127 (2008) 19-35.

24 Amos 5:11; Isa 5:5-6; Zeph 1:13; Jer 6:12.

25 Amos 9:14; Jer 29:5-6; 29:28; 31:5; Isa 62:8-9; 65:21-22; Ezek 28:26; 36:36.

26 Jacob Lauinger, »Literary Connections and Social Contexts: Approaches to Deuteronomy in Light of the Assyrian adê-Tradition«, HeBAI 8 (2019) 87-100.

27 Nathaniel B. Levtow, »Monumental Inscriptions and the Ritual Representation of War", in Warfare, Ritual, and Symbol in Biblical and Modern Contexts, ed. Brad E. Kelle, Frank Ritchel Ames and Jacob L. Wright (Atlanta: SBL, 2014) 25-46: 27, n. 3.

28 Similarly, Hans-Ulrich Steymans has shown that the EST reflects a sophisticated use of rhetoric conducive to oral delivery. See $»$ Die Neuassyrische Vertragsrhetorik der ,Vassal Treaties of Esarhaddon und das Deuteronomium«, in Das Deuteronomium, ed. G. Braulik and G. Vanoni, ÖBS 23 (Frankfurt am Main: Peter Lang, 2003) 89-152: 98-105. 
and monument. While our evidence is necessarily textual, the background which informed the futility curse in Deut 28:30 is oral, performative-and public. This recalls John Langshaw Austin's »Speech Act « theory, who described curses as performative utterances which are believed to have an efficacious effect: the thought world behind them attributes power to the spoken word. ${ }^{29}$ According to Philip Ravenhill, communal witnessing is essential in order to activate the power of the utterance. ${ }^{30}$ We might note the ceremonial pronouncements of blessings and curses in Deuteronomy 27, where the entire Israelite community is said to be present. ${ }^{31}$ Moreover, the threat envisioned by the curse is more encompassing than it first appears. As Jeremy Smoak has shown, in the Neo-Assyrian literary and iconographic traditions, the destruction of vegetation and households are frequently coupled with the threat of deportation. ${ }^{32}$ This is also the case in Deut 28:30, thus v. 32 goes on to threaten the deportation of one's children. Similarly, we find the curse in Amos 5:11 associated with the destruction of fortresses (v. 9), exile (v. 11), and wailing in the city street (v. 17). The curse in Zeph 1:13 is also found in the larger context of images of warfare in vv. 12-16. There is a metonymic element inherent to this curse: it threatens in real terms the loss of crops, household, and wife, but at the same time brings to mind the successful capture of a city, culminating in deportation. ${ }^{33}$ The futility curse of Deut 28:30, then, must be understood as reflecting a significant intimidation, a means of psychological warfare against those it was aimed at. Mediated through publicly displayed monuments and recited orally in the ritual context, such a curse constituted a well-known malediction whose threat went beyond its stated content to threaten capture and failure in warfare in general.

29 John Langshaw Austin, How to Do Things with Words (Oxford: Oxford University Press, 1962), 6-11.

30 Philip L. Ravenhill, »Religious Utterances and the Theory of Speech Acts«, in Language in Religious Practice, ed. William J. Samarin (Rowley: Newbury House Publishers, 1976) 26-39: 37.

31 The reciting of blessings and curses during public worship or gathering is also found in Josh 8:34; Deut 30:9; and 1Kgs 8.

32 Jeremy D. Smoak, "Assyrian Siege Warfare Imagery and the Background of a Biblical Curse", in Writing and Reading War: Rhetoric, Gender, and Ethics in Biblical and Modern Contexts, ed. Brad E. Kelle and Frank Ritchel Ames (Atlanta: SBL, 2008) 83-91.

33 These curses have long been connected to the threat of warfare. See Robert Bach, »Bauen und Pflanzen«, in Studien zur Theologie der alttestamentlichen Überlieferungen, ed. Rolf Rendtorff and Klaus Koch (Neukirchen-Vluyn: Neukirchener, 1961) 7-32; Daniel L. Smith, The Religion of the Landless: The Social Context of the Babylonian Exile (Bloomington: Meyer Stone, 1989), 130-134; Carey Ellen Walsh, The Fruit of the Vine: Viticulture in Ancient Israel (Winona Lake: Eisenbrauns, 2000), 63-7. 


\section{Rituals and Magic Against Maledictions in the Ancient Near East}

Actual ritual texts or legal prescriptions for war rituals are not found in the Hebrew Bible. However, scholars are increasingly beginning to consider the ritual dimensions of warfare represented in the Bible. ${ }^{34}$ Indeed, biblical literature provides a wealth of references to ritual strategies for securing military success such as the consultation of prophets (2Kgs 3), pronouncement of oaths (Judges 11), ritual archery (2Kgs 13:14-10), and the smashing of pots and figurines (Ps 2:9). Post-warfare rituals typically focus on reintegration, using the language of ritual sacrifice to justify killing in order to reduce personal responsibility. ${ }^{35}$ The offering of the spoils of war as votives to the temple (Num 31:48-54; Jos 6:19,24; 1Sam 22:10-13; 31:10) can thus be understood as atoning as well as commemorative. These war rituals have a number of purposes. They are communicative, demonstrating military power to the enemy. And they have psychological benefits to the agents involved, creating solidarity and conveying confidence in victory. ${ }^{36}$ Given the pervasive and significant intimidation threatened by the futility curse in the context of warfare, it seems reasonable that a ritual response was developed in order to confront it. Indeed, the Hebrew Bible presents a range of ways for circumventing curses by conventional means (Judg 17:2; 21:18-23; 1Sam 14:45). In the wider ancient Near East, maledictions can be similarly circumvented. By reading Deut 20:5-7 in light of these ritual responses to maledictions, the text can be productively understood as a warfare ritual specifically aimed against the threat of the futility curse, and so against the threat of losing in battle more generally.

The longest and most important Mesopotamian anti-witchcraft ritual is known as the Maqlû, or »burning «. ${ }^{37}$ The texts describe various rituals performed

34 See the essays collected in Brad E. Kelle, Frank Ritchel Ames and Jacob L. Wright, eds., Warfare, Ritual, and Symbol in Biblical and Modern Contexts (Atlanta: SBL, 2014).

35 Niditch, War in the Hebrew Bible, 28-55; Susan Niditch, »A Messy Business: Ritual Violence after the War", in Warfare, Ritual, and Symbol in Biblical and Modern Contexts, ed. Brad E. Kelle, Frank Ritchel Ames and Jacob L. Wright (Atlanta: SBL, 2014) 187-204; Brad E. Kelle, »Postwar Rituals of Return and Reintegration « in Warfare, Ritual, and Symbol in Biblical and Modern Contexts, ed. Brad E. Kelle, Frank Ritchel Ames and Jacob L. Wright (Atlanta: SBL, 2014) 205-243.

36 See Rüdiger Schmitt, "War Rituals in the Old Testament: Prophets, Kings, and the Ritual Preparation for Wars«, in Warfare, Ritual, and Symbol in Biblical and Modern Contexts, ed. Brad E. Kelle, Frank Ritchel Ames and Jacob L. Wright (Atlanta: SBL, 2014) 149-161.

37 See Tzvi Abush, The Magical Ceremony Maqlû: A Critical Edition (Leiden: Brill, 2016); and Daniel Schwemer, The Anti-Witchcraft Ritual Maqlû: The Cuneiform Sources of a Magic Ceremony from Ancient Mesopotamia (Wiesbaden: Harrassowitz Verlag, 2017). 
in order to remove maledictions from a person, including the burning of figurines representing the person thought to have brought about the evil witchcraft. ${ }^{38}$ The description of the ritual takes up one tablet; an accompanying eight tablets present the various incantations which were recited alongside the ritual actions. We might not at first think to compare the text of Deut 20:5-7 to the Maqlû, a ritual for removing witchcraft and so commonly understood as a type of magical spell. Daniel Schwemer, one of the foremost scholars on the Maqlû, describes magic as »an activity consisting of symbolic gestures (e. g., the burning of a substitute figurine), usually accompanied by recitations, performed by an expert (relying on transmitted knowledge) with the goal of effecting an immediate change and transformation of the object of the activity (e.g., the cure of an ill person or the removal of an agent of evil from a house). ${ }^{39}$ But if we interpret Deut 20:5-7 as an utterance performed specifically against the threat of the futility curse, then the appositeness of Schwemer's description become obvious: the symbolic gesture in this context constitutes the spoken utterance which is performed by an expert (the officers, although in the current literary context, a religious official is also present), with the goal of avoiding the curse. The oration in Deuteronomy might therefore be understood as type of defensive magic. ${ }^{40}$

In the Mesopotamian anti-witchcraft rituals, a »mirror-image« performance is often used in order to rid the sufferer of his complaint. ${ }^{41}$ This is a type of "sympathetic magic «, magic based on imitation or correspondence. ${ }^{42}$ By inverting the original pronouncement or formula, the malediction can be avoided or even removed. Saul Olyan has shown that this ritual strategy is also operative in biblical rites, exploring ritual inversion in the context of rituals employed for puni-

38 This recalls the Sefire Treaty inscriptions, texts which as we have already noted, share significant commonalities with the futility curses of Deuteronomy 28. In the context of the pronouncement of the curses, various objects are burnt, broken, blinded and cut including wax, a wax figurine, and a calf. These are curses of simile, clearly accompanied by ritual acts as indicated by the use of the demonstrative article: "just as this man of wax is blinded, so may Mati[el] be blinded!« (KAI 222 A1:39). However, here the effect is to bring about a malicious intention, rather than to remove one.

39 Daniel Schwemer, »The Ancient Near East «, in The Cambridge History of Magic and Witchcraft in the West: From Antiquity to the Present, ed. David J. Collins (Cambridge: Cambridge University Press, 2015) 17-51: 19.

40 On the problem of differentiating between magic and religion in the Hebrew Bible see Shawna Dolansky, Now You See It, Now You Don't: Biblical Perspectives on the Relationship Between Magic and Religion (Winona Lake: Eisenbrauns, 2008).

41 Schwemer, »The Ancient Near East«: 33.

42 On sympathetic magic, see already James G. Frazer, The Golden Bough: A Study in Magic and Religion, vol. 1, Abridged Edition (New York: Macmillan, 1922), 12-15; 43. 
tive purposes. ${ }^{43}$ The lexical and ideational commonalities between Deut 20:5-7 to the curses of futility concerning houses, vineyards and wives might therefore be understood as a type of inversion, utilizing the "mirror-image " of the curse as a counter measure, to deflect the malediction. The curse, itself an oral pronouncement, is undone by another spoken utterance, the oration in Deut 20:5-7. Indeed, the spoken word was essential to the performance of rituals for and against witchcraft in the Mesopotamian context. In order for the ritual to be binding, the verbal communication must be fixed, and accordingly this does not vary much between the individual sources. ${ }^{44}$ Thus curse utterances and the means to expel them are linguistically marked in ways that differentiates them from casual speech. ${ }^{45}$ And this is the case in Deut 20:5-7 and 28:30.

\title{
3 The Futility Curse and Deuteronomy 20
}

At first glance, Deut 20:5 and 28:30 do not provide an exact fit. Certainly, in both an individual is involved in building, bnh, producing a house, bayit. However, Deut 28:30 threatens houses in which a person is unable to yšb, "sit, dwell«, while Deut 20:5 is worried about another person $h n k$, dedicating it:

\begin{abstract}
Who among you has built a new house and not dedicated it? He may go home, lest he die in battle and someone else dedicate it.

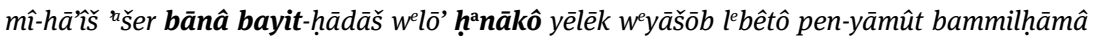

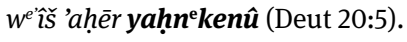

If you build a house, you shall not live in it.

bayit tibneh welō' tēšēb bô (Deut 28:30b).

The verb hnk is used elsewhere with respect to the dedication of Solomon's temple (1Kgs 8:63; cf. 1Chr 7:5). The derived noun $h^{a} n u k k a ̂$ is found in the context of the consecration of the temple altar (2Chr 7:9) and the rebuilt wall of Jerusalem

43 Saul M. Olyan, »Ritual Inversion in Biblical Representations of Punitive Rites«, in Worship, Women and War: Essays in Honor of Susan Niditch, ed. John J. Collins, T.M. Lemos and Saul M. Olyan, Brown Judaic Studies (Atlanta: SBL, 2015) 135-144.

44 Daniel Schwemer, »)Form Follows Function`? Rhetoric and Poetic Language in First Millennium Akkadian Incantation«, WdO 44 (2014) 263-288: $263 \mathrm{f}$.

45 This is also the case in the Greco-Roman world, see Hendrik S. Versnel, »The Poetics of the Magical Charm: An Essay on the Power of Words«, in Magic and Ritual in the Ancient World, ed. Paul A. Mirecki and Marvin W. Meyer (Leiden: Brill, 2002) 105-158. These are the »felicity conditions « which govern and ensure the efficacy of performatives, according to Austin's theory. See How to Do Things with Words, 6-11. 
(Neh 12:27). It seems therefore to have religious connotations. However, in these examples the references are all to public structures; there is no evidence for the practice of dedicating private houses in the Hebrew Bible. Instead, the sense of the word may be »to initiate, to begin to use «, ${ }^{46}$ bringing the verse much closer to the futility curse found in Deut 28:30 and elsewhere (cf. Amos 5:11; Zeph 1:13). In Deut 20:6, the language more precisely matches the curse:

Or who among you has planted a vineyard and not benefited from it? He may go home, lest he die in battle and someone else benefit from it.

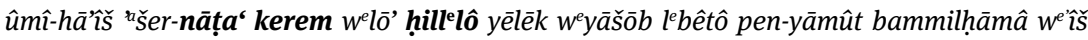
'aḥēr $y^{\mathrm{e}}$ ḥallelenû (Deut 20:6).

If you plant a vineyard, you shall not benefit from it.

kerem tiț̣a‘ $w^{e} \overline{o ̄}^{\prime} t^{e}$ hallellennû (Deut 28:30c).

In both these clauses, the individual plants ( $\left.n t^{\circ}\right)$ a vineyard (kerem). The verb hll in the piel is used in both verses with the meaning »to treat as common or profane«, which refers to the idea that the first produce of a new vineyard belongs to God (Lev 19:23-25; Jer 31:5). The planter has not yet had time to profane his vineyard, meaning that he himself has not yet been able to benefit from it. The language of Amos 5:11 which refers to the inability of the cursed individual to drink from the produce of the vineyard is therefore close in meaning though not as lexically exact.

Deut 20:7 and 28:30 both use the verb 'rs', »to betroth", to describe the man who has become engaged to a woman, but not yet consummated the union:

Or who among you has become engaged to a woman but has not married her? He may go home, lest he die in battle and someone else take her.

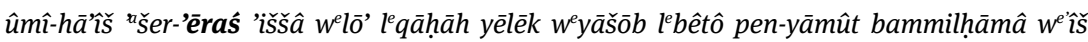
'aḥēr yiqqāḥennâ (Deut 20:7).

If you become engaged to a woman, another man shall violate her.

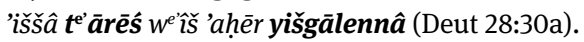

In 20:7, the verb used to describe the actions of the alternative individual who will frustrate the groomsman's desire for marriage is lqh, which can be used in the Hebrew Bible in a conjugal sense: »to take« a wife, for example, in Gen 11:29 and Exod 21:10. This is how the verb is clearly understood by a number of English translations (NRSV, NIV, NET): the man has become engaged to a woman, but

46 See Stefan C. Reif, »Dedication to hnnk«, VT 22 (1972) 495-501. 
another man will marry her. However, the verb can also be used with the more violent sense »to take« by force, that is, to rape, for example, in Gen 34:2, where Shechem »takes« Dinah. The verb is also used to describe the union between a man and his mother-in-law, sister, or sister-in-law in Lev 20:14, 17, 21, where these unions are condemned and accordingly cannot refer to a marriage but rather to an unlawful sexual union. In fact, lqh with the sense of marriage is more usually articulated as lāqah leiššâ, »to take a wife ${ }^{47}$ Accordingly, the more violent implications of lqh are likely in sight here. The idea in Deut 20:7 is therefore much closer to Deut 28:30 than it first appears: in the case of Deut 28:30, the woman will be »violated» by another man, using the verb šgl, »to violate«. This verb occurs elsewhere in Isa 13:16, Zech 14:2 and Jer 3:2. In each case, the Masoretic editors prompt the readers in the Qere to the less violent (and more common) škb, »to lie

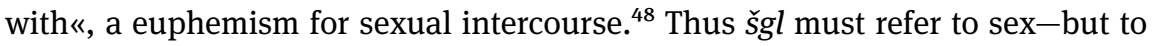
an obscene sex act, apparently too lewd for the Masoretes. ${ }^{49}$ Both the futility curse in Deut 28:30 and the exemption in Deut 20:7 are therefore concerned with the sexual violation of the woman.

Thus, each of the three curses of Deut 28:30 are reversed in 20:5-7, often using the exact same vocabulary and, even when the terminology is not a faithful match, providing exact commonalities in ideation. By strategically employing the linguistically marked language of the curse, Deut 20:5-7 would be well-understood by listeners as a type of behabitive which inverts the culturally specific language of malediction threatened by the futility curse. The command for the new groomsman, planter, or house builder to leave the ranks can thus be understood as a symbolic means for the troops to avoid failure in battle, neutralizing the threat of the curse. Without these individuals, the curse cannot befall the army. And since the curse stands not just for its specified contents but the threat of the loss in warfare in general-victory is therefore guaranteed.

In this essay, I have proposed exploring the military exemption from the law of war in light of the futility curse in Deut 28:30. By looking at the background of the curse in Neo-Assyrian and Northwest Semitic texts, I have highlighted the oral, performative aspect of the pronouncement of curses as well as the all-encompassing nature of the threat envisioned by the curse. There is a metonymic element inherent to the futility curse threatening houses in which one cannot reside and

47 DCH 4:573.

48 Albeit the term occurs often in the context of rape and incest (Gen 19:32,34,35; 34:2,7; 2Sam 13:11,14), and thus like šgl can also refer to illegitimate sexual relations.

49 The Qere reading is prompted by the necessity for the substitution of a less obscene term, see B. Megillah 25b. 
vineyards which one cannot benefit from, and thus the curse embodies failure in warfare more generally. It therefore has a specifically military context. But rather than merely an attempt to avoid the futility curse, Deut 20:5-7 can be productively understood as a ritual response to this military curse. Like the Mesopotamian rituals for avoiding witchcraft, the military exemption can be understood as a form of ritual inversion. The very orality of the futility curse is used against it in a spoken utterance which draws upon the culturally specific language of the curse. The original Sitz im Leben of these verses may therefore have been in a pre-war ritual specifically responding to the hegemonic aims of enemies as this crystallized in both the inscriptional and ritual contexts of ancient warfare. This has then been reinterpreted in light of other military orations found in the Hebrew Bible (Exod 14:13-14; Judg 4:14; 7:15; 2Sam 10:12), and the ritual context of the prescriptions have been lost. But by exploring the ritual and performative elements of Deut 20:5-7 in light of rituals for avoiding curses and maledictions from the ancient Near East, we can uncover this ritual background. The oration in Deut 20:5-7 inverts the malicious intentions of the futility curse by drawing upon the language of the curse and inverting it. Those who would suffer the curse are eliminated from the ranks, and with them the threat of an unsuccessful campaign is also eliminated, since the futility curse can no longer be activated against the troops. Deut 20:5-7 can thus be understood as a type of apotropaic, therapeutic ritual used to restore and maintain order in warfare, imbuing the soldiers with confidence before battle.

Abstract: This essay explores the military exemption of Deut 20:5-7 in light of the futility curse in Deut 28:30. By uncovering the social and ritual contexts of the futility curse, I argue that Deut 20:5-7 can be productively understood as a warfare ritual against the curse. I explore the ritual dimensions of Deut 20:5-7 in light of rituals for avoiding curses and maledictions from the ancient Near East, arguing that the original Sitz im Leben of these verses can be found in a pre-war ritual responding to the hegemonic aims of enemies as this crystallized in the inscriptional and ritual contexts of ancient warfare.

Keywords: Deuteronomy; Law of War; futility curse; warfare ritual; Maqlû.

Zusammenfassung: Der Aufsatz untersucht die Bestimmungen zur Befreiung vom Kriegsdienst in Dtn 20,5-7 im Lichte des Vergeblichkeitsfluches in Dtn 28,30. Der soziale und rituelle Kontext des Vergeblichkeitsfluches zeigt, dass Dtn 20,5-7 als Kriegsführungsritual gegen einen solchen Fluch verstanden werden kann. Sodann werden die rituellen Dimensionen von Deut 20,5-7 im Hinblick auf Rituale zur Vermeidung von Flüchen und Verwünschungen aus dem Alten Orient 
betrachtet: Der ursprüngliche Sitz im Leben dieser Verse ist in einem Vorkriegsritual zu finden ist, das auf die hegemonialen Ziele der Feinde reagiert, so wie es sich in den inschriftlichen und rituellen Kontexten der antiken Kriegsführung herauskristallisiert.

Schlagwörter: Deuteronomium; Kriegsrecht; Nutzlosigkeitsfluch; Kriegsführungsritual; Maqlû

Résumé: Cet article examine les dispositions relatives à l'exemption du service militaire en Dt 20,5-7 à la lumière de la malédiction de futilité en Dt 28,30. Le contexte social et rituel de cette malédiction montre que Dt 20,5-7 peut être compris comme un rituel de guerre contre une telle malédiction. Dt 20,5-7 est ensuite analysé à la lumière des rituels pour éviter les malé-dictions et les imprécations de l'Orient ancien : le Sitz im Leben originel de ces versets se trouve dans un rituel d'avant-guerre qui réagit aux visées hégémoniques de l'ennemi, tel qu'il est cristallisé dans les inscription et rituels de l'idéologie de la guerre.

Mots-clés: Deutéronome; droit de la guerre; malédiction d'inutilité; rituel de guerre; Maqlû 